\title{
Keperdataan Anak Diluar Nikah dalam Putusan Mahkamah Konstitusi dan Implikasinya terhadap Harta Warisan
}

\author{
Sari Pusvita* \\ Institut Agama Islam Negeri (IAIN) Sultan Thaha Saifuddin, \\ Jambi \\ Email: saripusvieta@gmail.com
}

\begin{abstract}
The decision of constitutional court No. 46/PUU-VIII/2010 is a new step in the field of family law in Indonesia. The problems of this research are what is the basic consideration of the constitutional court judge grant the petition of determining civil status of the illegitimate children; what are the effects of explicit and implicit law for the determining of the constitutional court to the illegitimate children; how is contemplation of the Islamic law to the legacy of the illegitimate children as the implication of the constitutional court decision. This is a library research. It only focuses on some data in library. The resource secondary data which contains primary and secondary law resources. The approaches used are legislation and conceptual approaches. All of data are analysed by using descriptive analysis. From the research can be concluded that the basic consideration of the constitutional court judge is based on four factors. They are sociologies, technology, and knowledge improvement, punishment, and law protection for the children. The explicit impact is there is an assurance law for the illegitimate children. In the contrary, the implicit one is it will make a confusion in a family law, if it is included adultery (zina), living together without any legitimate marriage (samen leven), and other free
\end{abstract}

* Program Pascasarjana Institut Agama Islam Negeri (IAIN) Sultan Thaha Saifuddin, Jambi. 
relationship. It is explained in the Islamic law that illegitimate children have no relation with their father. So that, there is no a reason to get the legacy.

Keywords: Child Status, Constitutional Court Decision, Compilation of Islamic Law.

\begin{abstract}
Abstrak
Putusan mahkamah konstitusi Nomor 46 / PUU-VIII / 2010 merupakan langkah di bidang hukum keluarga di Indonesia. Hakim konstitusi mengabulkan petisi untuk menentukan status perdata bagi anak-anak lahir dari pernikahan kedua orang tuanya tidak tertulis oleh Pegawai Pencatatan Nikah (PKN). Dalam penelitian ini, peneliti ingin menggali apa efek dari hukum eksplisit dan implisit untuk menentukan pengadilan konstitusional bagi anak-anak yang tersebut diatas; bagaimana Kontemplasi Hukum Islam terhadap warisan anakanak yang lahir dari orang tua yang tidak memiliki status pernikahan resmi sebagai implikasi dari putusan Mahkamah Konstitusi. Ini adalah penelitian perpustakaan dan hanya berfokus pada beberapa data yang bersumber di perpustakaan. Pendekatan yang digunakan adalah pendekatan perundangundangan dan konseptual. Semua data dianalisis dengan menggunakan analisis deskriptif. Dari hasil penelitian, hakim konstitusi berdasarkan empat faktor. Mereka adalah sosiologi, teknologi, dan peningkatan pengetahuan, hukuman, dan perlindungan hukum bagi anak-anak. Dampak eksplisit adalah hukum jaminan untuk anak-anak yang tidak sah dari status perwakinan orang tuanya. Sebaliknya, yang tersirat akan membuat kebingungan dalam hukum keluarga, jika itu termasuk perzinaan (zina), hidup bersama tanpa perkawinan yang sah (samen leven), dan hubungan bebas lainnya. Dijelaskan dalam hukum Islam bahwa anak yang lahir dari perzinaan tidak memiliki hubungan dengan ayah mereka. Jadi, tidak ada alasan untuk mendapatkan warisan.
\end{abstract}

Kata Kunci: Status Anak, Keputusan Mahkamah Konstitusi, Kompelasi Hukum Islam.

\title{
Pendahuluan
}

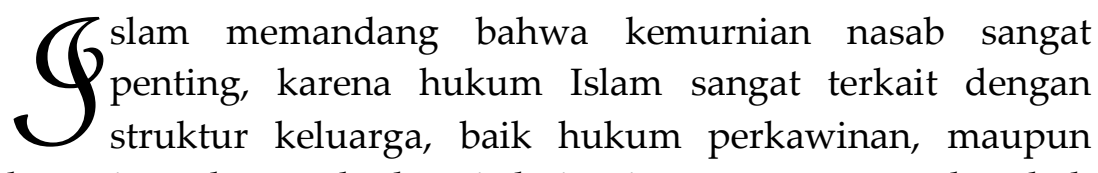
kewarisan dengan berbagai derivasinya yang merupakan hak

Ulul Albab: Jurnal Studi dan Penelitian Hukum Islam 
Keperdataan Anak diluar Nikah .... $\mid 33$

perdata dalam hukum Islam. Baik menyangkut hak nasab, hak perwalian, hak memperoleh nafkah dan hak mendapatkan warisan. Bahkan konsep ke-mahraman- atau kemuhriman dalam Islam akibat hubungan persemendaan atau perkawinan. ${ }^{1} \mathrm{Hal}$ ini sebagaimana firman Allah dalam QS. Al-Furqan [25] yang artinya "Dan Dia (pula) yang menciptakan manusia dari air lalu Dia jadikan manusia itu (punya) keturunan dan mushaharah dan adalah Tuhanmu Maha Kuasa". (QS. Al-Furqan [25]: 54)²

Di samping itu seorang anak juga diharamkan menasabkan dirinya kepada laki-laki selain ayah kandungnya sendiri, sebagaimana disebutkan dalam sebuah hadis:

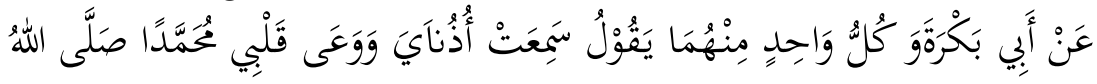

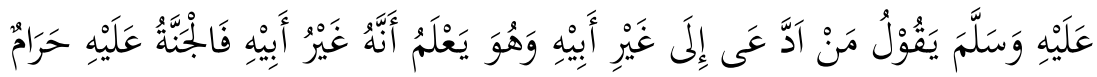
Artinya:

"Dari Abu Bakrah berkata, kedua telingaku mendengar dan hatiku menghafal Nabi Muhammad SAW, bersabda: 'Barangsiapa yang menasabkan dirinya kepada lelaki lain selain ayahnya, padahal ia mengetahui bahwa lelaki itu bukan ayahnya maka diharamkan baginya surga". ${ }^{3}$

Hadis di atas menjelaskan bahwa seseorang tidak diperkenankan menasabkan dirinya kepada lelaki lain selain ayah kandungnya, jika seseorang menasabkan dirinya pada selain ayah kandungnya maka dia termasuk berdosa dan diharamkan surga baginya. Dengan demikian, surah Al-Furqan [25]: 54, dan hadis di atas merupakan penjelas bahwa kemurnian nasab harus dipelihara dan dijaga dengan baik.

Dalam hukum perkawinan yang berlaku di Indonesia, yaitu Undang-undang No.1 Tahun 1974 Pasal 43 ayat (1)

${ }^{1}$ M. Nurul Irfan, Nasab dan Status Anak dalam Hukum Islam, (Jakarta: Amzah, 2013), 7.

2 Departemen Agama RI, Al-Qur'an danTerjemahnya, (Bandung: Diponegoro, 2005), 366.

${ }^{3}$ Imam Bukhari, Shahih Bukhari, Jilid 4. hal. 15 hadis No. 6766. 
34| Sari Pusvita

menyatakan bahwa anak yang lahir di luar perkawinan hanya mempunyai hubungan perdata dengan ibunya dan keluarga ibunya. ${ }^{4}$ Dan dalam Kompilasi Hukum Islam (KHI) Pasal 100 menyatakan bahwa anak yang lahir di luar perkawinan hanya mempunyai nasab dengan ibunya dan keluarga ibunya. ${ }^{5}$ Artinya Pasal 43 ayat (1) UUP dan Pasal 100 KHI, menjelaskan bahwa apabila anak lahir di luar perkawinan yang sah maka hubungan keperdataan hanya ada pada ibunya dan keluarga ibunya.

Dalam perspektif Hukum Islam nasab anak terhadap ayah bisa terjadi karena tiga hal, yaitu:

Pertama, Nasab Melalui Pernikahan yang Sah, Ulama Fiqh sepakat bahwa anak yang lahir dari seorang wanita dalam suatu perkawinan yang sah dinasabkan kepada suami wanita tersebut. Hal ini sejalan dengan bunyi hadis: ${ }^{6}$

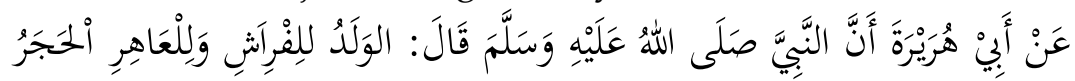
Artinya:

"dari Abu Hurairah, bahwa Nabi SAW bersabda "anak itu bagi firasy dan bagi yang berzina di-hukum-batu (rajam)".

Hadis di atas menegaskan bahwa nasab anak yang lahir dalam dan karena perkawinan yang sah adalah dihubungkan kepada ayah kandungnya. Ketentuan ini tidak berlaku disebabkan kehamilan yang dilakukan karena perzinaan antara seorang laki-laki dan perempuan. Dalam konteks ini nasab anak hanya dihubungkan kepada ibu dan keluarganya saja.

Kedua, Nasab Melalui Pernikahan yang Fäsid, Pernikahan fäsid adalah pernikahan yang dilangsungkan dalam keadaan kekurangan syarat, baik keseluruhan maupun sebagian, seperti tidak ada wali (bagi Mazhab Hanafi wali tidak menjadi syarat

${ }^{4}$ Undang-undang Perkawinan Indonesia, (Jakarta: Cemerlang, tt), 16.

${ }^{5}$ Departemen Agama RI, Kompilasi Hukum Islam, (Jakarta: Depag RI, 2001), 51 .

${ }^{6}$ Muhammad Nashiruddin Al-Albani, Shahih Sunan Nasa'I, Jilid 2 (Jakarta: Pustaka Azzam, 2006), 794.

Ulul Albab: Jurnal Studi dan Penelitian Hukum Islam 
Keperdataan Anak diluar Nikah .... $\mid 35$

sahnya perkawinan) dan tidak ada saksi atau saksinya itu adalah saksi palsu. ${ }^{7}$

Ketiga, Nasab Anak dari Hubungan Badan Secara Syubhat. Kata al-Shubhät berarti kemiripan, keserupaan, persamaan dan ketidakjelasan. Dalam kaitannya dengan kajian Hukum, istilah syubhat dapat diinterpretasikan sebagai suatu situasi dan kondisi adanya ketidakjelasan dalam sebuah peristiwa Hukum, karenanya ketentuan Hukumnya tidak dapat diketahui secara pasti, apakah berada dalam wilayah halal atau haram. Dalam pengertian lain, syubhat adalah sesuatu yang tidak jelas apakah benar atau tidak, atau masih mengandung probabilitas antara benar dan salah, sekaligus tidak bisa ditarjihkan mana yang validitas Hukumnya lebih kuat. Hubungan syubhat ini ada dua macam, yaitu: syubhat dalam akad dan syubhat dalam tindakan. ${ }^{8}$

${ }^{7}$ Menurut ulama mazhab Hanafi nikah fäsid itu ada enam macam, yaitu 1) Nikah tanpa saksi, 2) Nikah Mut'ah, 3) Nikah dengan cara menghimpun lima wanita sekaligus, 4) Nikah dengan menghimpun wanita dan bibinya atau saudara kandungnya, 5) Nikah dengan wanita yang telah punya suami, dan 6) Nikah dengan salah seorang mahram, sedangkan Nikah Fāsid menurut Mazhab Maliki adalah 1) Nikah dengan mahram, 2) Nikah dengan cara menghimpun dua wanita, 3) Nikah dengan istri sebagai istri kelima, 4) Nikah Mut'ah, 5) Nikah dengan wanita yang masih dalam 'iddah. Dalam Mazhab Syafi'i yang dikategorikan nikah fasid adalah 1) Nikah Shigar, 2) Nikah Mut'ah 3) Nikah dalam masa Ihram, 4) Poliandri, 5) Nikah dengan wanita yang masih dalam masa 'iddah atau istibra', 6) Nikah dengan wanita yang dalam keadaan hamil, 7) Nikah dengan wanita yang bukan ahli kitab, 8) Nikah dengan wanita yang selalu pindah-pindah agama, 9) Menikahkan wanita dengan lelaki kafir atau menikah dengan wanita murtad, sedangkan kateori nikah fäsid dalam mazhab Hanbali adalah 1) Nikah Shigar, 2) Nikah Muhallil, 3) Nikah Mut'ah, 4) Nikah Muaqqat, yaitu nikah yang dihubungkan dengan suatu kondisi. Lihat Wahbah Zuhaili, jilid VII, 109-120 dan Ahmad Muhammad Assaf, Al-Ahkam Al-Fiqhiyyah Fi al-Mazahib Al-Islamiyah Al-Arba'ah (Beirut: Dar al-ihya al-ulum, 1988), jilid II, 323.

${ }^{8}$ M. Nurul Irfan, Nasab dan Status Anak..., 185-186. 
36| Sari Pusvita

Menurut Wahbah Az-Zuhaili ${ }^{9}$ ada lima macam hak anak terhadap orang tuanya, yaitu hak nasab (keturunan), hak radha' (menyusui), hak hadhanah (pemeliharaan), hak walayah (wali), dan hak nafaqah. Dengan terpenuhinya lima kebutuhan ini, orang tua akan mampu mengantarkan anaknya dalam kondisi yang siap untuk seorang anak menjadi anggota keluarga melalui garis nasab, sehingga secara hukum anak berhak atas hubungan hukum tersebut. ${ }^{10}$

Namun, persoalan tentang hak-hak anak ini muncul ketika anak yang dilahirkan adalah hasil dari pernikahan yang tidak dicatatkan oleh Pegawai Pencatat Nikah (PPN) atau dari hubungan perzinaan. Dari pernikahan yang tidak dicatatkan, anak yang lahir akan mengalami kesulitan dalam mendapatkan identitas berupa akta kelahiran. Padahal akta kelahiran merupakan hak anak pertama yang seharusnya diberikan oleh negara. Undang-undang perlindungan anak menyatakan dengan jelas bahwa setiap anak dengan jelas berhak mendapatkan identitas. Identitas atas kelahiran merupakan suatu bentuk pengakuan dari orang tua dan juga negara.

Agar penelitian ini lebih terarah, maka rumusan masalah yang dijadikan bahan pijakan dalam penelitian ini adalah (1) Apa faktor pertimbangan Hakim Mahkamah Konstitusi mengabulkan permohonan penetapan status perdata anak luar nikah; (2) Bagaimana akibat Hukum yang tersurat dan tersirat dari putusan Mahkamah Konstitusi bagi anak yang lahir di luar nikah?; (3) Bagaimana tinjauan Hukum Islam terhadap hak waris anak luar nikah sebagai implikasi dari putusan Mahkamah Konstitusi?

9 Saiful Amin Ghofur, Profil Para Mufassir Al-Qur'an, (Yogyakarta: Pustaka Insan Madani, 2008), 174.

10 Wahbah Az-Zuhaili, Figh Islam Wa Adillatuhu, Jilid 10, diterjemahkan oleh Abdul Hayyie Al-Kattanie (Jakarta: Gema Insani, 2011), 25.

Ulul Albab: Jurnal Studi dan Penelitian Hukum Islam 
Keperdataan Anak diluar Nikah .... $\mid 37$

\section{Metodologi}

Pendekatan yang paling memungkinkan dalam peneitian ini adalah: Legislation Approach (pendekatan perundang-undangan) dan Conceptual Approach (pendekatan konsep). Dalam metode pendekatan perundang-undangan peneliti perlu memahami hierarki, dan asas-asas dalam peraturan perundang-undangan. Menurut Pasal 1 angka 2 UU No. 10 Tahun 2004, peraturan perundang-undangan adalah peraturan yang tertulis yang dibentuk oleh lembaga negara atau pejabat yang berwenang dan mengikat secara umum. Dari pengertian itu secara singkat dapat dikatakan bahwa yang dimaksud dengan statue berupa legislasi dan regulasi. ${ }^{11}$

Kemudian, Conceptual Approach (Pendekatan Konseptual). Dalam pendekatan konseptual peneliti beranjak dari pandangan-pandangan dan doktrin-doktrin yang berkembang di dalam Ilmu Hukum. Tidak dapat disangkal bahwa "kepentingan umum" merupakan konsep hukum bukan konsep politik atau ekonomi. Dengan mempelajari pandanganpandangan dan doktrin-doktrin di dalam Ilmu Hukum, peneliti akan menemukan ide-ide yang melahirkan pengertianpengertian hukum, konsep-konsep hukum, dan asas-asas hukum yang relevan dengan isu yang dihadapi. ${ }^{12}$

\section{Hasil dan Pembahasan}

a. Dasar Pertimbangan Hakim Mahkamah Konstitusi (MK) Mengabulkan Permohonan Penetapan Status Perdata Anak Luar Nikah

Pembacaan Putusan untuk pengujian Undang-undang Putusan No. 46/PUU-VIII/2010 oleh Ketua Majelis Hakim MK beserta anggota Majelis Hakim lainnya yang dilaksanakan pada tanggal 17 Februari 2012. Persidangan tersebut membacakan perihal Putusan yang berisi berupa pertimbangan hukum dan

${ }^{11}$ Peter Mahmud Marzuki, Penelitian Hukum, (Jakarta: Kencana, 2010), 97.

${ }^{12}$ Ibid. 97. 
38| Sari Pusvita

telah membaca, mendengar, dan memeriksa permohonan yang disertai alat bukti dan keterangan tertulis yang diajukan oleh pemohon. ${ }^{13}$

Dalam amar putusannya MK menyatakan mengabulkan permohonan pemohon untuk sebagian, yaitu pada Pasal 43 ayat (1) yang menyatakan "Anak yang dilahirkan di luar perkawinan hanya mempunyai hubungan perdata dengan ibunya dan keluarga ibunya", bertentangan dengan UUD RI tahun 1945 sepanjang dimaknai menghilangkan hubungan perdata dengan laki-laki yang dapat dibuktikan berdasarkan ilmu pengetahuan dan teknologi dan/atau alat bukti lain menurut hukum ternyata mempunyai hubungan darah dengan ayahnya. Sehingga ayat tersebut harus dibaca "Anak yang dilahirkan di luar perkawinan mempunyai hubungan perdata dengan ibunya dan keluarga ibunya serta dengan laki-laki sebagai ayahnya yang dapat dibuktikan berdasarkan ilmu pengetahuan dan teknologi dan/atau alat bukti lain menurut hukum mempunyai hubungan darah, termasuk hubungan perdata dengan keluarga ayahnya". ${ }^{14}$

Amar putusan selanjutnya berbunyi, dan menolak permohonan para pemohon untuk selain dan selebihnya. Yaitu berkaitan dengan Pasal 2 ayat (2) UUP No. 1 Tahun 1974 tentang pencatatan perkawinanan. ${ }^{15}$ Alasan penolakan MK karena pencatatan perkawinan merupakan kewajiban administratif yang harus dipenuhi oleh setiap warga negara Indonesia. Tujuannya sesuai dengan tanggung jawab negara pada warga negaranya yaitu untuk memberikan jaminan perlindungan, pemajuan, penegakan, dan pemenuhan hak asasi manusia yang bersangkutan. Selanjutnya perkawinan merupakan suatu

${ }^{13}$ Eddo Febriansyah, Tinjauan Yuridis Putusan Mahkamah Konstitusi Nomor 46/PUU-VIII/2010 Tentang Kedudukan Anak diluar Nikah yang Diakui dalam Pembagian Warisan, Unnes Law Journal, diakses tanggal 12 April 2016, pukul 06.30 WIB.

${ }^{14}$ Amar Putusan Mahkamah Konstitusi, 36-37.

${ }^{15}$ Ibid., 36-37.

Ulul Albab: Jurnal Studi dan Penelitian Hukum Islam 
Keperdataan Anak diluar Nikah .... $\mid 39$

perbuatan hukum. Oleh karena itu, pencatatan perkawinan merupakan suatu akta autentik. Sehingga perlindungan dan pelayanan oleh negara terkait dengan hak-hak yang timbul dari suatu perkawinan yang bersangkutan dapat terselenggara secara efektif dan efisien. ${ }^{16}$ Faktor-faktor yang menjadi pertimbangan MK mengabulkan permohonan para Pemohon tersebut adalah:

1. Faktor sosiologis. Anak yang dilahirkan tanpa memiliki kejelasan status ayah seringkali mendapatkan perlakuan yang tidak adil dan stigma negatif di tengah-tengah masyarakat. Sehingga hukum harus memberi perlindungan dan kepastian hukum yang adil terhadap status seorang anak yang dilahirkan dan hak-hak yang ada padanya, termasuk terhadap anak yang dilahirkan meskipun keabsahan perkawinannya masih dipersengketakan;

2. Faktor kemajuan IPTEK. Dengan adanya kemajuan Ilmu Pengetahuan dan Teknologi seperti sekarang ini, tes DNA merupakan salah satu cara yang dapat digunakan untuk mengetahui kejelasan hubungan status anak dengan bapak biologisnya secara akurat.

3. Faktor pemberian punisment. Maksudnya lahirnya seorang anak karena adanya hubungan seksual (coitus) antara seorang wanita dan seorang pria, sehingga tidak adil jika hanya membebankan hak-hak keperdataannya hanya kepada seorang wanita yang melahirkannya dan membebaskan lakilaki tersebut dari tanggung jawabnya sebagai seorang ayah dan bersamaan dengan itu hukum meniadakan hak-hak anak terhadap lelaki tersebut sebagai ayahnya. Lebih-lebih manakala berdasarkan perkembangan teknologi yang ada memungkinkan dapat dibuktikan bahwa seorang anak itu merupakan anak dari laki-laki tersebut.

${ }^{16}$ Ibid., 33-34.

Vol. 1, No. 2, April 2018, 31-51 
40| Sari Pusvita

4. Faktor perlindungan hukum terhadap anak. Hal ini sesuai dengan Pasal 3 UU No. 23 tahun 2002 tentang perlindungan anak, tujuan dari perlindungan anak untuk menjamin terpenuhinya hak-hak anak agar dapat hidup, tumbuh, berkembang, berpartisipasi secara optimal sesuai dengan harkat dan martabat kemanusiaan, serta mendapat perlindungan dari kekerasan dan disdkriminasi, demi terwujudnya anak Indonesia yang berkualitas, berakhlak mulia dan sejahtera.

Dengan adanya beberapa faktor pertimbangan hakim seperti yang telah dijelaskan di atas menjadi legal reasoning bagi MK untuk mengeluarkan putusan No. 46/PUU-VIII/2010 tentang status perdata anak luar nikah.

Dalam hal ini, pernikahan siri adalah pernikahan yang sah menurut agama. Dalam Hukum Islam telah dijelaskan bahwa pernikahan adalah anjuran yang sebaiknya dilaksanakan bagi yang telah mampu baik secara zahir maupun batin. Sebagaimana hadis Nabi yang berbunyi: ${ }^{17}$

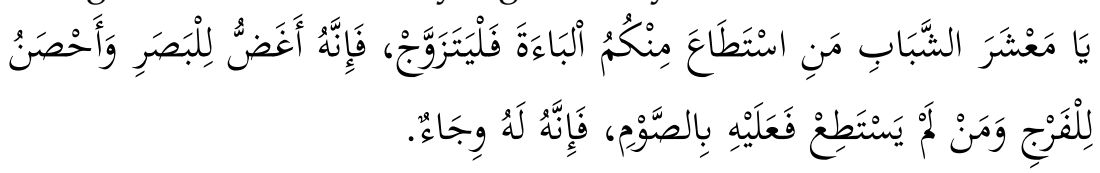

Artinya:

"Wahai kelompok pemuda, barangsiapa diantara kalian mampu menikah, menikahlah. Sesungguhnya nikah itu dapat lebih menundukkan pandangan mata dan dapat lebih membentengi (menjaga) kemaluan. Barangsiapa tidak mampu menikah, hendaklah berpuasa karena puasa dapat menekan syahwat.

Dengan adanya dalil di atas menunjukkan bahwa pernikahan merupakan salah satu cara bagi yang telah mampu untuk menghindarkan diri dari perbuatan zina. Karena zina merupakan suatu perbuatan keji dan suatu jalan yang buruk.

${ }_{17}$ Zaki Al-Din 'Abd Al-Azhim Al-Mundziri, Ringkasan Shahih Muslim (Bandung: Mizan, 2013), 444.

Ulul Albab: Jurnal Studi dan Penelitian Hukum Islam 
Sebagaimana firman Allah Surah Al-Isra' [17] ayat: 32 yang artinya: "Dan janganlah kamu mendekati zina; Sesungguhnya zina itu adalah suatu perbuatan yang keji. dan suatu jalan yang buruk." (Al-Isra'[17]: 32).

b. Akibat Hukum Yang Tersurat Dan Tersirat Dari Putusan Mahkamah Konstitusi Bagi Anak Yang Lahir Di Luar Nikah

Putusan MK No. 46/PUU-VIII/2010 adalah sebuah putusan yang memberi warna bagi perkembangan hukum keluarga di Indonesia. Dengan adanya putusan tersebut menjadikan anak-anak luar nikah dapat meminta hak-hak keperdataannya kepada ayah biologisnya selama dapat dibuktikan dengan ilmu pengetahuan dan/atau alat bukti lain yang menurut hukum ternyata mempunyai hubungan darah dengan ayahnya.

Rumusan Putusan MK No. 46/PUU-VIII/2010 pada Pasal 43 berbunyi "Anak yang dilahirkan di luar perkawinan mempunyai hubungan perdata dengan ibunya dan keluarga ibunya serta dengan laki-laki sebagai ayahnya, yang dapat dibuktikan berdasarkan ilmu pengetahuan dan teknologi dan/atau alat bukti lain menurut hukum mempunyai hubungan darah, termasuk hubungan perdata dengan keluarga ayahnya".

Secara tekstual, putusan MK tersebut menjelaskan bahwa frasa "anak yang dilahirkan di luar perkawinan" mengandung makna anak yang dilahirkan dari pernikahan yang sah menurut agama namun tidak dicatatkan pada lembaga yang berwenang, dan anak yang lahir tanpa adanya ikatan perkawinan seperti kumpul kebo, perselingkuhan dan sebagainya. Kesimpulan ini didapat dari pemahaman Undangundang Perkawinan No. 1 Tahun 1974. Karena pemohon mengajukan permohonan judicial review pada MK pada Undangundang Perkawinan No. 1 Tahun 1974 Pasal 2 ayat (2) dan Pasal 43 ayat (1), maka pemahaman secara tekstual dari Putusan MK juga berangkat dari pemaknaan anak yang dilahirkan diluar nikah menurut Undang-undang Perkawinan No. 1 Tahun 1974. 
$42 \mid$ Sari Pusvita

Dengan demikian, maka anak yang dilahirkan di luar nikah sesuai Undang-undang Perkawinan mempunyai hubungan perdata tidak hanya dengan ibu dan keluarga ibunya saja, namun juga dengan laki-laki sebagai ayahnya, yang dapat dibuktikan berdasarkan ilmu pengetahuan dan teknologi dan/atau alat bukti lain menurut hukum mempunyai hubungan darah, termasuk hubungan perdata dengan keluarga ayahnya.

Karena statusnya yang suci, maka seharusnya seorang anak tidak hanya mendapat pengakuan dari ibu kandungnya tetapi juga dari ayah kandungnya yang dapat dibuktikan dengan kemajuan IPTEK yaitu tes DNA atau dengan alat bukti lain yang diakui oleh Undang-Undang. Hal inilah yang menjadi dasar bagi MK untuk mengeluarkan putusan No. 46/PUUVIII/2010 tersebut. Sehingga hak-hak anak tidak hanya didapatkan dari ibunya dan keluarga ibunya saja namun juga didapatkannya pula dari ayah biologisnya. Mulai dari nafkah, biaya pendidikan, biaya kesehatan, perwalian dan waris. Sehingga mereka (anak hasil zina) juga mendapatkan kehidupan dan penghidupan yang layak.

Berdasarkan pemahaman secara kontekstual frasa "anak yang lahir di luar perkawinan" adalah anak yang lahir dari pernikahan siri, yaitu pernikahan yang telah sesuai dengan syarat dan rukun dalam agama Islam namun belum sah menurut negara secara legal formal. Sehingga jika dihubungkan dengan Putusan MK tersebut, "anak yang lahir di luar perkawinan" harus dipahami sebagai anak dari pernikahan siri selama bisa dibuktikan dengan ilmu pengetahuan dan teknologi dan/atau alat bukti lain menurut hukum mempunyai hubungan darah, maka mempunyai hubungan perdata tidak hanya dari ibu dan keluarga ibunya tetapi juga dari ayah dan keluarga ayahnya. Sehingga bagi anak yang lahir tanpa adanya ikatan perkawinan tidak termasuk dalam konteks Putusan MK ini.

Hal ini juga mendapatkan penegasan Lebih lanjut dari Ketua MK saat itu bahwa yang dimaksud majelis dengan frasa 
Keperdataan Anak diluar Nikah .... 43

"Anak diluar Nikah" bukan anak hasil zina, melainkan hasil nikah siri. Hubungan perdata yang diberikan kepada anak di luar nikah tidak bertentangan dengan nasab, waris dan wali nikah. Hak yang dapat dituntut anak di luar nikah yang tidak diatur fiqh antara lain: berupa hak menuntut pembiayaan atau hak menuntut ganti rugi karena perbuatan melawan hukum yang merugikan orang lain seperti yang diatur dalam Pasal 1365 KUHP atau hak untuk menuntut karena ingkar janji. Intinya adalah hak-hak perdata selain hak nasab, hak waris, wali nikah, atau hak perdata apapun yang tidak terkait dengan prinsipprinsip munakahat sesuai fiqh.

Putusan MK tidak hanya mengikat para pihak yang terlibat dalam perkara (intra partes), tetapi juga harus ditaati oleh siapapun disebut dengan putusan yang bersifat erge omnes. Ketentuan mengikat umum putusan MK ini dikarenakan sifat hukum publiknya. ${ }^{18}$

Dengan demikian, maka Putusan MK No. 46/PUUVIII/2010 merupakan putusan yang bersifat final and binding. Bersifat mengikat, dan tidak adanya upaya hukum lebih lanjut, seperti banding, kasasi, ataupun peninjauan kembali dari Putusan yang sudah dibacakan untuk umum. Dalam hal ini semakin jelaslah bahwa anak yang lahir di luar nikah telah mendapatkan kejelasan di dalam pandangan hukum, mendapatkan hak dan kedudukan di dalam hukum di Indonesia.

\section{c. Tinjauan Hukum Islam terhadap hak waris anak luar nikah sebagai implikasi dari putusan Mahkamah Konstitusi}

Dalam hukum Islam, para ulama sepakat mengatakan bahwa nasab seseorang kepada Ibunya terjadi dengan sebab kehamilan sebagai akibat hubungan seksual yang dilakukannya dengan seorang laki-laki, baik itu dilakukan berdasarkan akad

${ }^{18}$ Maruarar Siahaan, Hukum Acara Mahkamah Konstitusi (Jakarta: Sinar Grafika, 2012), 160. 
44 Sari Pusvita

nikah yang sah maupun melalui hubungan gelap, samen leven, perselingkuhan, dan perzinaan. Sedangkan nasab anak terhadap ayah kandungnya menurut Wahbah Az-Zuhaili sebagaimana yang dikutip oleh M. Nurul Irfan adalah hanya bisa terjadi dan memungkinkan dibentuk melalui tiga cara, yaitu pertama, melalui perkawinan yang sah, kedua, melalui pernikahan yang fāsid atau batil, dan ketiga, melalui hubungan badan secara syubhat. ${ }^{19}$

Sedangkan para ulama sepakat menyatakan bahwa perzinaan bukan penyebab timbulnya hubungan nasab anak dan ayah, sehingga anak zina tidak boleh dihubungkan dengan nasab ayahnya, meskipun secara biologis berasal dari benih lakilaki yang menzinai ibunya. Alasan mereka bahwa nasab itu merupakan karunia dan nikmat, sedangkan perzinaan itu merupakan tindak pidana (jarimah) yang sama sekali tidak layak mendapatkan balasan nikmat, melainkan balasan berupa hukuman, baik rajam maupun dera seratus kali dan pengasingan, ${ }^{20}$ selain itu alasan kuatnya adalah sabda Nabi dalam sebuah hadis: ${ }^{21}$

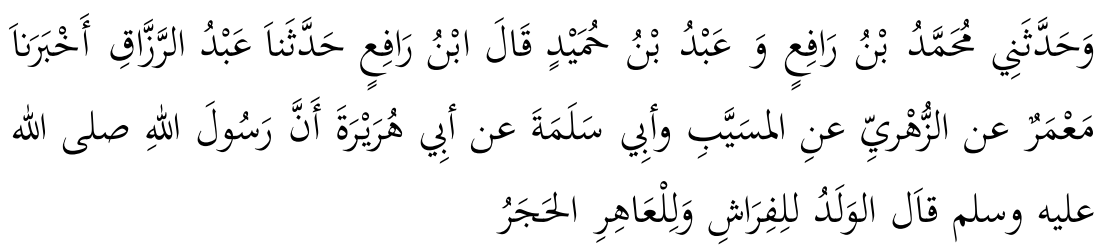

Artinya:

"Dan telah menceritakan kepadaku Muhammad bin Rafi' dan Abd bin Humaid, Ibnu Rafi' mengatakan, telah menceritakan kepada kami Abdur Razaq telah mengabarkan kepada kami Ma'mar dari Az-Zuhri dari Ibnu Musayyab dan Abu Salamah dari Abu Hurairah bahwasanya

${ }^{19}$ M. Nurul Irfan, Nasab dan Status Anak...., 61.

${ }^{20}$ Ibid., 88.

${ }^{21}$ Muslim bin Al-Hajjaj Al-Qusyairi An-Naisaburi, Ensiklopedia Hadits 3 Shahih Muslim 2, diterjemahkan oleh Ferdinand dkk, (Jakarta: Almahira, 2012).

Ulul Albab: Jurnal Studi dan Penelitian Hukum Islam 
Keperdataan Anak diluar Nikah .... 45

Rasulullah SAW bersabda: "Seorang anak adalah untuk pemilik ranjang, sedangkan yang menzinai tidak memiliki hak atasnya".

Hadis di atas menunjukkan bahwa anak yang lahir dari pernikahan yang sah dihubungkan nasabnya kepada ayahnya. Implikasi dari hubungan nasab tersebut otomatis membuat anak tersebut memiliki hubungan keperdataan dengan ayahnya sehingga ia berhak mendapatkan waris, nafkah, perwalian serta hak keperdataan lainnya. Sebaliknya anak yang lahir di luar pernikahan yang sah tidak dapat dihubungkan nasabnya kepada ayahnya namun hanya kepada ibu dan keluarga ibunya. $^{22}$

Dengan demikian, Implikasi dari tidak adanya hubungan nasab antara anak dengan ayah akan sangat kelihatan dalam beberapa aspek yuridis, di mana laki-laki yang secara biologis adalah ayah kandungnya itu berkedudukan sebagai orang lain, sehingga tidak wajib memberi nafkah, tidak ada hubungan waris mewarisi, bahkan seandainya anak zina itu perempuan, "ayah" kandungnya tidak diperbolehkan berduaan dengannya, serta laki-laki pezina itu tidak dapat menjadi wali dalam pernikahan anak perempuan zinanya, sebab antara keduanya tidak ada hubungan sama sekali dalam syariat Islam. ${ }^{23}$

Meskipun anak tersebut adalah anak zina, namun sebagai manusia yang berperasaan dan memiliki hati nurani bahkan harga diri tentu akan sangat menderita dengan predikatpredikat rendah yang melekat padanya, sementara dirinya pun pada hakikatnya tidak menginginkan lahir ke dunia ini dengan lantaran perbuatan nista yang dilakukan oleh kedua orang tuanya.

Oleh karena itu untuk mengatasi polemik ini, maka MUI memberikan tanggapan yang ditandatangani oleh K.H. Ma'ruf Amin dan Drs. H. M. Ichwan Sam yang isinya:

${ }^{22}$ Chuzaimah T Yanggo dan Hafiz Anshary (Eds), Problematika Hukum Kontemporer, (Jakarta: Pustaka Firdaus, 2009), 135.

${ }^{23}$ M. Nurul Irfan, Nasab dan Status Anak..., 89.

Vol. 1, No. 2, April 2018, 31-51 
46| Sari Pusvita

1. Anak hasil zina tidak mempunyai hubungan nasab, wali nikah, waris, dan nafaqah dengan lelaki yang menyebabkan kelahirannya.

2. Anak hasil zina hanya mempunyai hubungan nasab, waris, dan nafaqah dengan ibunya dan keluarga ibunya.

3. Anak hasil zina tidak menanggung dosa perzinaan yang dilakukan oleh orang yang mengakibatkan kelahirannya.

4. Pezina dikenakan hukuman hadd oleh pihak yang berwenang, untuk kepentingan menjaga keturunan yang sah (hifzhu alnasl).

5. Pemerintah berwenang menjatuhkan hukuman $t a^{\prime} z i r$ lelaki pezina yang mengakibatkan lahirnya anak dengan mewajibkannya untuk :

a. mencukupi kebutuhan hidup anak tersebut;

b. memberikan harta setelah ia meninggal melalui wasiat wajibah.

6. Hukuman sebagaimana dimaksud nomor 5 bertujuan melindungi anak, bukan untuk mensahkan hubungan nasab antara anak tersebut dengan lelaki yang mengakibatkan kelahirannya. ${ }^{24}$

Dengan adanya putusan MUI No. 11 Tahun 2012 Tentang Kedudukan Anak Hasil Zina Dan Perlakuan Terhadapnya merupakan bentuk respon dari adanya putusan MK No. 46/PUU-VIII/2010 tentang status anak di luar nikah. Menurut MUI jika yang dimaksud dengan status anak luar nikah adalah adanya hubungan perdata antara anak hasil zina dengan lakilaki yang mengakibatkan kelahirannya dan keluarganya adalah juga hubungan nasab, waris, wali, dan nafaqah, maka keputusan MK tersebut bertentangan dengan ajaran Islam. Namun, jika hanya bertujuan untuk melindungi hak-hak anak hasil zina tidak dilakukan dengan memberikan hubungan perdata kepada laki-

24 Ketentuan Hukum Fatwa MUI No. 11 Tahun 2012 tentang Kedudukan Anak Hasil Zina dan Perlakuan Terhadapnya.

Ulul Albab: Jurnal Studi dan Penelitian Hukum Islam 
laki yang mengakibatkan kelahirannya, melainkan dengan menjatuhkan $t a^{\prime} z i r$ kepada laki-laki tersebut berupa kewajiban mencukupi kebutuhan anak tersebut atau memberikan harta setelah ia meninggal melalui wasiat wajibah, maka MUI pun menyetujuinya. ${ }^{25}$

Hukuman ta'zir yang dimaksudkan oleh MUI adalah sebagai bentuk hukuman dan tanggung jawab laki-laki yang berzina. Dengan demikian, maka anak hasil zina tidak mendapatkan hak kewarisan. Karena sebagaimana yang dijelaskan dalam KHI Pasal 171 huruf c dijelaskan: "Ahli waris adalah orang yang pada saat meninggal dunia mempunyai hubungan darah atau hubungan perkawinan dengan pewaris, beragama Islam dan tidak terhalang karena hukum untuk menjadi ahli waris". ${ }^{26}$

Sebab-sebab adanya kewarisan menurut hukum Islam adalah adanya hubungan pernasaban. Disini jelas bahwa anak hasil zina menurut hukum Islam hanya memiliki hubungan nasab dengan ibunya. Sehingga anak tersebut mendapatkan kewarisan dari pihak Ibu. Sebagaimana diatur dalam KHI Pasal 186 yang menyatakan: "Anak yang lahir di luar perkawinan hanya memiliki hubungan saling mewaris dengan ibunya dan keluarga dari pihak ibunya". ${ }^{27}$

Dalam hal ini KHI memiliki kesamaan dengan UUP tentang kedudukan dan hak-hak anak luar kawin sebelum lahirnya putusan MK No. 46/PUU-VIII/2010, yaitu mereka hanya mewaris atau memiliki hubungan perdata dengan ibunya dan keluarga ibunya. Dan tidak memiliki hubungan perdata dengan ayahnya ataupun keluarga ayahnya. Sehingga anak zina dalam hukum Islam tidak memiliki hak untuk dapat mewaris dengan ayah biologisnya. Namun mendapatkan wasiat wajibah, hal ini bisa dikatakan bahwa kedudukan anak luar nikah memiliki

\footnotetext{
${ }^{25}$ Ibid.

${ }^{26}$ Departemen Agama RI, Kompilasi Hukum ...., 81.

${ }^{27}$ Departemen Agama RI, Kompilasi Hukum ...., 86.
} 
48| Sari Pusvita

kesamaan dengan anak angkat dan ahli waris yang beda agama dengan pewarisnya. Yang mana hal ini pernah terjadi dalam putusan MA RI No. 51K/AG/1999 yang memperbaiki putusan Pengadilan Agama Yogyakarta No. 83/1997/YK tentang penetapan ahli waris yang bukan Islam berdasarkan wasiat wajibah.

\section{Kesimpulan}

Dari pembahasan diatas, dapat disimpulkan beberapa point penting dalam keperdataan anak di luar nikah dalam putusan Mahkamah Konstitusi dan implikasinya terhadap harta warisan. Terdapat sedikitnya empat faktor mengenai pertimbangan hakim MK mengabulkan permohonan pemohon dalam penetapan status perdata anak diluar nikah yaitu faktor sosiologi, faktor kemajuan IPTEK, faktor pemberian punisment dan faktor perlindungan hukum terhadap anak. Dalam Putusan MK No. 46/PUU-VIII/2010, MK melihat adanya perlakuan yang tidak adil bahkan menjadi stigma negatif dikalangan masyarakat terhadap anak yang lahir tanpa adanya kejelasan status perkawinan kedua orang tuanya. Sehingga dibutuhkan kepastian hukum yang dapat melingdungi hak-hak anak yang lahir status tersebut diatas. Maka dari itu, perkembangan IPTEK khususnya melalui tes DNA dapat dimanfaatkan dalam rangka menopang keakuratan status anak secara biologis dengan ayahnya yang lahir di luar nikah. Selain itu, MK melihat adanya ketidakadilan terhadap seorang wanita atau ibu yang harus menanggung semua urusan perdata anaknya setelah melahirkan anaknya dengan status diluar nikah. Sedangkan lelaki yang sudah menghamilinya bebas dari tanggungjawab terhadap anaknya. Terlebih lagi, MK mempertimbangkan perlindungan anak khususnya hak-hak mereka agar tetap hidup, tumbuh, dan berkembang layaknya anak-anak yang lain yang lahir dari kedua orang tua dengan perkawinan yang sah secara agama dan hukum negara.

Ulul Albab: Jurnal Studi dan Penelitian Hukum Islam 
Putusan MK No. 46/PUU-VIII/2010 tersebut secara tidak langsung juga memiliki akibat hukum yang tersurat dan tersirat sebagai konsekuensinya. Hal ini khusunya dalam memahami maksud dari kalimat anak yang dilahirkan diluar perkawinan, karena secara tersurat kalimat tersebut memiliki makna lebih kepada anak yang lahir dari pernikahan siri, karena walaupun secara agama sudah sah mencakup seluruh syarat dan rukun nikah, akan tetapi jika belum tertulis secara administrasi di KUA maka dianggap masih ilegal secara administrasi negara. Namun demikian, apa yang tersirat dari kalimat putusan MK diatas adalah diluar perkawinan dalam arti anak yang lahir dari hubungan perzinaan, perselingkuhan, kumpul kebo (semen leven) dan hubungan bebas lainnya. Sedangkan dalam agama Islam sudah jelas zina adalah suatu perbuatan yang keji dan dilarang keras. Maka dari itu, hal inilah yang menjadi polemik di dalam hukum keluarga di Indonesia terkait dengan putusan MK tersebut diatas.

Anak luar nikah dalam hukum Islam diartikan sama dengan anak zina. Para ulama sepakat menyatakan bahwa perzinaan bukan penyebab timbulnya hubungan nasab anak dan ayah, sehingga anak zina tidak boleh dihubungkan dengan nasab ayahnya, meskipun secara biologis berasal dari benih lakilaki yang menzinai ibunya. Alasan mereka bahwa nasab itu merupakan karunia dan nikmat, sedangkan perzinaan itu merupakan tindak pidana (jarimah) yang sama sekali tidak layak mendapatkan balasan nikmat, melainkan balasan berupa hukuman rajam bagi pezina muhsan dan dera seratus kali dan pengasingan selama satu tahun bagi pezina ghairu muhsan.

Karenanya, untuk memberikan perlindungan hukum bagi anak yang lahir di luar nikah karena zina dan sejenisnya maka MUI telah memberikan solusi hukumnya. Pertama, dengan menjatuhkan ta'zir kepada laki-laki tersebut berupa kewajiban mencukupi kebutuhan anak tersebut yang bentuk dan kadarnya diserahkan kepada ulil amri (pihak yang berwenang menetapkan 
50| Sari Pusvita

hukuman), kedua, dengan memberikan harta setelah ia meninggal melalui wasiat wajibah.

Namun pada Putusan MK No. 46/PUU-VIII/2010 tersebut tidak ada pembatasan secara jelas bahwa Putusan tersebut hanya berlaku bagi anak yang lahir dari nikah siri. sebagaimana diketahui bahwa adanya pengertian anak yang tidak sah dalam UU No. 1 Tahun 1974 adalah anak yang dilahirkan dalam pernikahan yang sah menurut agama namun tidak dicatatkan pada lembaga yang berwenang dan kedua, anak yang tidak sah adalah anak yang dilahirkan tidak dalam ikatan pernikahan yang sah.

Sehingga, ratio legis, yang mendasari Putusan MK tidak hanya melegitimasi "hubungan perdata" dan polarisasi hak anak dan kewajiban laki-laki biologis, melainkan didasari hadirnya satu pembuktian berbasis ilmu pengetahuan dan teknologi yang menjadi dasar ada dan tidak adanya hak anak luar nikah dalam menuntut hak-hak keperdataan baik materiil maupun immateriil. Sehingga anak luar nikah hasil nikah siri dan anak luar nikah yang lahir karena tidak adanya hubungan pernikahan sama-sama mendapatkan hak yang sama dihadapan hukum. Dengan demikian, hak dan kedudukan anak luar nikah sama dengan hak dan kedudukan anak sah.

Dari hasil penelitian ini, peneliti mencoba memberikan sumbangan pemikiran kepada pemerintah untuk segera menyusun juklak atau juknis dari putusan MK No. 46/PUUVIII/2010. Dengan tujuan agar dapat diketahui dengan jelas maksud dari putusan tersebut. Sehingga tidak menimbulkan multi tafsir. Dan aparat penegak hukum dapat melaksanakan putusan tersebut dengan sebenarnya. Serta masyarakat tidak dibingungkan dengan adanya berbagai pendapat yang terkait dengan putusan MK tersebut.

Ulul Albab: Jurnal Studi dan Penelitian Hukum Islam 
Keperdataan Anak diluar Nikah .... $\mid 51$

\section{Daftar Pustaka}

al-Mundziri, Zaki Al-Din 'Abd Al-Azhim. 2013. Ringkasan Shahih Muslim. Bandung: Mizan.

Amar Putusan Mahkamah Konstitusi No. 46/PUU-VIII/2010.

al-Naisaburi, Muslim bin Al-Hajjaj Al-Qusyairi. 2012. Ensiklopedia Hadits 3 Shahih Muslim 2. Diterjemahkan dari Bahasa Arab oleh Ferdinand Dkk. Jakarta: Almahira.

Assaf, Ahmad Muhammad. 1988. Al-Ahkam Al-Fiqhiyyah Fi alMazahib Al-Islamiyah Al-Arba'ah. Beirut: Dar al-Ihya alulum.

Az-Zuhaili, Wahbah. 2011. Figh Islam Wa Adillatuhu, jilid 10. Diterjemahkan dari Bahasa Arab oleh Abdul Hayyie AlKattanie. Jakarta: Gema Insani.

Bukhari, Imam. Shahih Bukhari, Jilid 4. hal. 15 hadis No. 6766.

Departemen Agama RI. 2005. Al-Qur'an danTerjemahnya. Bandung: Diponegoro.

Departemen Agama RI. 2001. Kompilasi Hukum Islam. Jakarta. Fatwa MUI No. 11 Tahun 2012 tentang Kedudukan Anak Hasil Zina dan Perlakuan Terhadapnya.

Febriansyah, Eddo. Tinjauan Yuridis Putusan Mahkamah Konstitusi Nomor 46/PUU-VIII/2010 Tentang Kedudukan Anak diluar Nikah yang Diakui dalam Pembagian Warisan. Unnes Law Journal. 4 (1) 2015.

Ghofur, Saiful Amin. 2008. Profil Para Mufassir Al-Qur'an. Yogyakarta: Pustaka Insan Madani.

Irfan, M. Nurul. 2013. Nasab dan Status Anak dalam Hukum Islam. Jakarta: Amzah.

Marzuki, Peter Mahmud. 2010. Penelitian Hukum. Jakarta: Kencana.

Siahaan, Muarar. 2012. Hukum Acara Mahkamah Konstitusi. Jakarta: Sinar Grafika..

Undang-undang Perkawinan Indonesia. TT. Jakarta: Cemerlang. Yanggo, Chuzaimah T, dan Hafiz Anshary. Edisi IV. 2009. Problematika Hukum Kontemporer. Jakarta: Pustaka Firdaus. 